Article

\title{
Isolation and Characterization of Polysaccharides from Oysters (Crassostrea gigas) with Anti-Tumor Activities Using an Aqueous Two-Phase System
}

\author{
Kit-Leong Cheong ${ }^{+}$(D), Li-Xuan Xia ${ }^{\dagger}$ and Yang Liu * \\ Guangdong Provincial Key Laboratory of Marine Biotechnology, STU-UNIVPM Joint Algal Research Center, \\ Department of Biology, College of Science, Shantou University, Shantou 515063, Guangdong, China; \\ klcheong@stu.edu.cn (K.-L.C.); 141xxia@stu.edu.cn (L.-X.X.) \\ * Correspondence: liuyanglft@stu.edu.cn; Tel.:+86-0754-8650-2749 \\ + These authors contributed equally to this work.
}

Received: 8 October 2017; Accepted: 25 October 2017; Published: 1 November 2017

\begin{abstract}
In this study, a simple aqueous two-phase system (ATPS) was employed for concurrent purification of oyster polysaccharides. The chemical structure and anti-tumor activities of purified oyster polysaccharides (OP-1) were also investigated. Under optimal ATPS conditions, oyster polysaccharides can be partitioned in the bottom phase with $67.02 \%$ extraction efficiency. The molecular weight of OP- 1 was determined as $3480 \mathrm{Da}$. OP- 1 is a $(1 \rightarrow 4)$ - $\alpha$-D-glucosyl backbone and branching points located at $O-3$ of glucose with a terminal-D-Glcp. The anti-tumor activity assay showed that OP-1 exhibited good activities, including promotion of splenocyte proliferation, IL-2 release, and inhibition of HepG2 cell proliferation. Additionally, OP-1 had no in vivo toxicity. This finding suggests that ATPS is a much simpler and greener system, and it opens up new possibilities in the large-scale separation of active polysaccharides from oysters. OP-1 could be used by the health food and pharmaceutical therapies as potential anti-cancer adjuvants.
\end{abstract}

Keywords: Crassostrea gigas; polysaccharides; aqueous two-phase system; anti-tumor activity

\section{Introduction}

Pacific oysters (Crassostrea gigas) are the largest molluscan group cultured in China. They grow fast and spread quickly due to their good tolerance of environmental alterations [1]; this feature has helped them become an abundant ocean-derived resource. Pacific oysters are referred to as "the milk of the sea" because they are an excellent source of high-quality nutrition, which include polysaccharides, protein, peptides, lipids, phenolic compounds, and minerals [2,3]. In addition to their nutritional value, oysters could be utilized as potential functional food exhibiting beneficial health effects. Oysters are an adequate resource with high functional value; therefore, they have much potential in the functional food industry.

Functional studies have been conducted on oyster polysaccharides, including the potential interleukin-2 (IL-2) effects on peripheral blood mononuclear cells [4], modulation of antigen-induced splenocyte proliferation and T-cell cytokine expression [5], and enhancement of the phenoloxidase activity of hemocyte suspensions [6]. Recently, some bioactive polysaccharides have been isolated from oysters and have shown hepatoprotective [7], anti-hypertensive [8], and other anti-oxidant activities [9]. Usually, polysaccharides' biological activities are closely correlated to their molecular mass, chemical structure, monosaccharide composition, and linkage type $[10,11]$. Therefore, a better understanding of oyster polysaccharides' chemical structures and physical properties is essential for the successful interpretation of the correlation between the structure and bioactivity of these molecules and would also be beneficial for the future application of these types of polysaccharides in functional food areas. 
Polysaccharides are a type of biomacromolecule that have wide applications in functional food, pharmaceutical, and industrial research fields. The method by which pure polysaccharides are effectively obtained is the basis of studies on this subject. The traditional methods for polysaccharide purification include ethanol precipitation, de-proteinization by the Sevag method, and ion-exchange and size exclusion chromatography $[12,13]$. However, these conventional methods are time-consuming, have laborious procedures and high operating costs, and involve organic solvents. An aqueous two-phase extraction system (ATPS) is a liquid-liquid separation technique based on the formation of two immiscible water-rich phases above certain critical concentrations of two mutually incompatible solutes [14]. ATPS has been successfully used to separate and purify flavonoids [15], small organic molecules [16], DNA [17], proteins [18,19], and polysaccharides [20] from fruits, plants, and herbs. APTSs are environmentally friendly, low-cost, easy to operate, and high in efficiency, and they have been used to separate and purify bioactive polysaccharides on a large scale in a single step. The most commonly explored type of ATPS in recent years for separation of polysaccharide/proteins is the polymer-salt system. High-molecular-weight hyaluronic acid was purified with a polyethylene glycol/potassium phosphate system, and nearly all of the hyaluronic acid in the salt-rich bottom phase and its purity reached almost $100 \%$ [21]. Xing and $\mathrm{Li}$ purified the aloe from bovine serum albumin with a PEG6000/( $\left(\mathrm{NH}_{4}\right)_{2} \mathrm{SO}_{4}$ system, and partitioned the aloe polysaccharides in the bottom phase. This phase separation and partitioning behaviour of aloe polysaccharides may be influenced by $\mathrm{NaCl}, \mathrm{pH}$, and $\mathrm{Gu}(\mathrm{SCN})_{2}$ [22]. A polymer-salt system consisting of ethylene-oxide- $\beta$-propylene-oxide- $\beta$-ethylene-oxide and $\mathrm{NaH}_{2} \mathrm{PO}_{4}$ was used to partition the Lycium barbarum extract. The L. barbarum polysaccharides were partitioned to the bottom phase with a high recovery ratio and purity [23].

In this study, a simple ATPS was employed to separate polysaccharides and proteins produced by Pacific oysters. The partitioning efficiency of polysaccharides and proteins and the influences of different processing parameters (such as composition and molecular mass of PEG) were analyzed in detail. The chemical structures and biological activities of the purified polysaccharides were also analyzed in detail. The results could be helpful in further understanding the structure-function relationship of these polysaccharides, and could pave the way for the potential use of oyster polysaccharides as functional foods or therapeutic agents.

\section{Results and Discussion}

\subsection{Selection of the Optimal Aqueous Two-Phase System}

To determine the optimal ATPS, the partitioning of oyster polysaccharides and proteins in ATPS at room temperature was investigated. The test systems are shown in Table 1. PEG/ammonium sulfate with different compositions and constant volume ratios were used. It can be seen that oyster polysaccharides were enriched in the bottom phase. A high polysaccharide extraction efficiency (about 71.84-89.42\%) was found in the bottom phase of the PEG-1000/ammonium sulfate system. At the same time, the protein was also found in the bottom phase with an extraction efficiency of $64.43-83.38 \%$. In the PEG-4000/ammonium sulfate system, the tie line length (TLL) increment caused a shift in the protein from the bottom to the top phase. The PEG-4000/ammonium sulfate system ( $2.2102 \mathrm{~g}: 0.1319 \mathrm{~g}, w / w$ ) with a TLL of 45 showed a relatively low protein extraction efficiency (about 15.59\%) with a high polysaccharide concentration, and it showed that a large portion of protein was enriched in the top phase after the phase separation process. However, it may lose about $30.09 \%$ of polysaccharides in the top phase.

The ethanol/ammonium sulfate system with different compositions was further investigated. It can be seen that the ethanol/ammonium sulfate system had lower protein recovery in the bottom phase when compared with the PEG/ammonium sulfate system (Table 1) because more protein was in the middle phase. Accordingly, with an increase in TLL, the recovery of polysaccharides in the bottom phase decreased because the strong salting-out effect led to an increase in salt concentration. The increase in salt concentration led to less available free water to dissolve the oyster polysaccharides, resulting in decreased polysaccharide recovery. Therefore, $0.1770 \mathrm{~g}$ of ethanol 
and $0.2729 \mathrm{~g}$ of ammonium sulfate were selected for oyster polysaccharide partitioning. About $67.02 \%$ of polysaccharides were obtained in the bottom phase, and only $12.12 \%$ of the polysaccharides were lost in the top phase. After phase separation, the bottom phase was collected and dialyzed against water for $24 \mathrm{~h}$. The retentate in the dialysis bag (a molecular weight cut-off of $500 \mathrm{Da}$ ) was concentrated in a vacuum evaporator and then lyophilized to dryness (Figure 1).

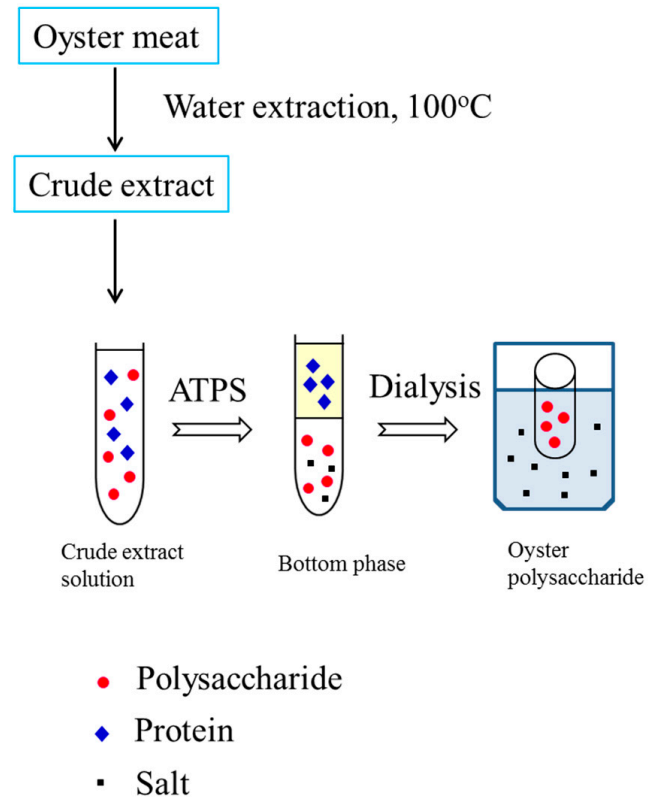

Figure 1. Flow chart of extraction, separation, and purification of polysaccharides from oysters using an aqueous two-phase system.

Table 1. Effect of different compositions of PEG, ethanol and ammonium sulfate, tie line length, and volume ratio on oyster polysaccharide content in aqueous two-phase systems.

\begin{tabular}{|c|c|c|c|c|c|c|c|}
\hline \multirow{2}{*}{\multicolumn{2}{|c|}{ Composition $(w / w)$}} & \multirow{2}{*}{$\begin{array}{l}\text { Tie Line } \\
\text { Length }\end{array}$} & \multirow{2}{*}{$\begin{array}{c}\text { Volume } \\
\text { Ratio }\end{array}$} & \multicolumn{2}{|c|}{ Recovery of Polysaccharides (\%) } & \multicolumn{2}{|c|}{ Recovery of Protein (\%) } \\
\hline & & & & \multirow[t]{2}{*}{ Top Phase } & \multirow[t]{2}{*}{ Bottom Phase } & \multirow[t]{2}{*}{ Top Phase } & \multirow[t]{2}{*}{ Bottom Phase } \\
\hline PEG-1000 & $\mathrm{AS}^{\mathrm{a}}$ & & & & & & \\
\hline 0.2270 & 0.1764 & 30 & $1.02 \pm 0.01$ & $5.71 \pm 0.31$ & $83.88 \pm 0.19$ & $14.68 \pm 0.25$ & $83.38 \pm 0.31$ \\
\hline 0.2348 & 0.1796 & 35 & $1.06 \pm 0.04$ & $6.92 \pm 0.17$ & $73.25 \pm 0.27$ & $8.59 \pm 0.07$ & $77.76 \pm 0.25$ \\
\hline 0.2432 & 0.1834 & 40 & $1.03 \pm 0.01$ & $8.16 \pm 0.28$ & $89.42 \pm 0.33$ & $11.83 \pm 0.12$ & $55.47 \pm 0.33$ \\
\hline 0.2520 & 0.1876 & 45 & $1.04 \pm 0.02$ & $8.92 \pm 0.10$ & $71.84 \pm 0.32$ & $20.09 \pm 0.12$ & $72.23 \pm 0.23$ \\
\hline 0.2613 & 0.1923 & 50 & $1.03 \pm 0.02$ & $8.61 \pm 0.13$ & $72.60 \pm 0.21$ & $18.67 \pm 0.27$ & $64.43 \pm 0.29$ \\
\hline PEG-2000 & AS & & & & & & \\
\hline 0.1524 & 0.1153 & 30 & $1.06 \pm 0.03$ & $8.79 \pm 0.22$ & $69.61 \pm 0.17$ & $5.71 \pm 0.22$ & $83.88 \pm 0.45$ \\
\hline 0.1697 & 0.1228 & 35 & $1.04 \pm 0.04$ & $6.25 \pm 0.13$ & $49.08 \pm 0.23$ & $6.92 \pm 0.25$ & $73.25 \pm 0.33$ \\
\hline 0.1870 & 0.1306 & 40 & $1.02 \pm 0.01$ & $5.93 \pm 0.05$ & $29.50 \pm 0.39$ & $8.16 \pm 0.09$ & $89.42 \pm 0.37$ \\
\hline 0.2045 & 0.1389 & 45 & $1.03 \pm 0.02$ & $5.55 \pm 0.09$ & $37.84 \pm 0.26$ & $3.92 \pm 0.01$ & $81.84 \pm 0.31$ \\
\hline 0.2221 & 0.1477 & 50 & $1.02 \pm 0.02$ & $9.67 \pm 0.14$ & $36.02 \pm 0.31$ & $2.61 \pm 0.01$ & $72.60 \pm 0.47$ \\
\hline PEG-4000 & AS & & & & & & \\
\hline 0.1721 & 0.1102 & 30 & $1.03 \pm 0.02$ & $14.68 \pm 0.17$ & $83.38 \pm 0.39$ & $12.74 \pm 0.01$ & $52.64 \pm 0.31$ \\
\hline 0.1841 & 0.1167 & 35 & $1.06 \pm 0.04$ & $8.59 \pm 0.16$ & $77.76 \pm 0.43$ & $12.77 \pm 0.05$ & $67.35 \pm 0.22$ \\
\hline 0.1966 & 0.1238 & 40 & $1.05 \pm 0.04$ & $18.20 \pm 0.08$ & $73.46 \pm 0.32$ & $8.24 \pm 0.01$ & $52.86 \pm 0.30$ \\
\hline 0.2102 & 0.1319 & 45 & $1.02 \pm 0.02$ & $30.09 \pm 0.23$ & $62.23 \pm 0.28$ & $36.26 \pm 0.13$ & $15.59 \pm 0.27$ \\
\hline 0.2238 & 0.1404 & 50 & $1.05 \pm 0.02$ & $38.67 \pm 0.32$ & $54.43 \pm 0.19$ & $35.62 \pm 0.16$ & $10.44 \pm 0.04$ \\
\hline Ethanol & AS & & & & & & \\
\hline 0.1770 & 0.2729 & 35 & $1.05 \pm 0.03$ & $12.12 \pm 0.11$ & $67.02 \pm 0.33$ & $25.01 \pm 0.11$ & $18.13 \pm 0.29$ \\
\hline 0.1844 & 0.2749 & 40 & $1.02 \pm 0.01$ & $13.47 \pm 0.18$ & $65.35 \pm 0.21$ & $23.92 \pm 0.34$ & $21.28 \pm 0.17$ \\
\hline 0.1930 & 0.2776 & 45 & $1.04 \pm 0.01$ & $12.24 \pm 0.09$ & $52.86 \pm 0.44$ & $44.69 \pm 0.31$ & $21.91 \pm 0.13$ \\
\hline 0.2030 & 0.2811 & 50 & $1.04 \pm 0.02$ & $26.26 \pm 0.37$ & $45.59 \pm 0.23$ & $45.13 \pm 0.42$ & $22.08 \pm 0.22$ \\
\hline 0.2120 & 0.2845 & 55 & $1.03 \pm 0.03$ & $25.62 \pm 0.27$ & $37.44 \pm 0.23$ & $45.62 \pm 0.37$ & $26.05 \pm 0.21$ \\
\hline
\end{tabular}

a AS: ammonium sulfate. 


\subsection{Purity and Homogeneity}

The lyophilized purified polysaccharides were in the form of a white powder, named OP-1. The weight-average molecular weight $\left(M_{\mathrm{W}}\right)$ and purity were analyzed by high-performance gel-permeation chromatography (HPPGC). A homogeneous peak appeared in the HPGPC elution profile of OP-1, with an $M_{\mathrm{w}}$ based on a column calibration of $3480 \mathrm{Da}$.

\subsection{Chemical Structures of the Purified Polysaccharides}

The monosaccharide composition of OP-1 is only glucose, as detected through the high performance liquid chromatography (HPLC) coupled with an evaporative light scattering detector (ELSD) of the OP-1 hydrolysate. The glycosyl-linkage of OP-1 was identified through methylation analysis. The GC-MS of the alditol acetates from methylated OP-1 revealed the presence of 1,5-di-O-acetyl-2,3,4,6-tetra-O-methyl-D-glucitol, 1,4,5-tri-O-acetyl-2,3,6-tri-O-methyl-D-glucitol, and 1,3,4,5-tetra-O-acetyl-2,6-di-O-methyl-D-glucitol derivatives at a molar ratio of 1.3:9.5:1. These results indicated that OP-1 exhibited an $(1 \rightarrow 4)$-linked backbone with branching points located at $O-3$ of Glc $p$ with terminal-D-Glc $p$ as a side chain. Meanwhile, the degree of branching was calculated as $24 \%$, according to the Tao et al. report [24]: $\mathrm{DB}=\frac{\left(N_{T}+N_{B}\right)}{\left(N_{T}+N_{B}+N_{L}\right)}$, where $N_{T}, N_{B}$, and $N_{L}$ are the total numbers of the terminal residues, branched residues, and linear residues, respectively.

The spectra of ${ }^{1} \mathrm{H}$ NMR and ${ }^{13} \mathrm{C}$ NMR of OP-1 are shown in Figure 2. The values of the chemical shifts found in the NMR spectrum of OP-1 are summarized in Table 2. The anomeric protons of Residues A, B, and $\mathbf{C}$ had chemical shifts larger than $\delta 5.00$, suggesting that these residues were $\alpha$-linked. The presence of residues of $\alpha$-linked residues was identical to that found via FTIR. The signal around $\delta 5.43$ overlapped with broad peaks, suggesting that there were some branches in $\alpha-(1 \rightarrow 4)$-linked residues [25]. The up-field signals between $\delta 3.9$ and $\delta 3.4$ were attributed to the proton resonances of $\mathrm{H}-2$ to $\mathrm{H}-6$. The signals in the ${ }^{13} \mathrm{C}$ NMR spectra indicated that all of the residues $(\mathbf{A}, \mathbf{B}$, and C) of OP-1 share an $\alpha$ anomeric configuration based on the fact that the chemical shifts of glucose is $\delta 100.0$ [26]. A signal observed at $\delta 77.6$ ppm was assigned to the resonance of C-4 of 4 -linked- $\alpha$-Glc.

The HSQC (Figure 2c) and HMBC (Figure 2d) spectra of OP-1 provided anomeric intra-residue and inter-residue correlations, respectively. The HSQC technique provided correlations between the carbon and its attached protons (as listed in Table 2). The correlation signals can be employed as the starting point to completely assign all ${ }^{1} \mathrm{H}$ and ${ }^{13} \mathrm{C}$ signals of OP-1. Based on the HMBC interpretation, the chemical shifts of C-3, C-4, C-5, and C- 6 of $\alpha-(1 \rightarrow 4)$-Glc $p$ were assigned as $\delta 73.6, \delta 78.0, \delta 71.8$, and $\delta 61.0$, respectively. A down-field shift of signal of C-6 $(\delta 61.0)$, combined with the cross peak of $\delta 3.69(\mathrm{H}-4)$ with $\delta 78.0$ in the HSQC spectrum, may indicate the presence of the $\alpha$-Glcp- $(1 \rightarrow$ residues linked at the $O-4$ position. More structural information of OP-1 and the assignments of NMR resonances were recorded on the basis of analysis of HSQC and HMBC spectra. The inter-residue HMBC correlations from $\mathrm{H}-1$ of residue $\mathbf{A}$ to C-4

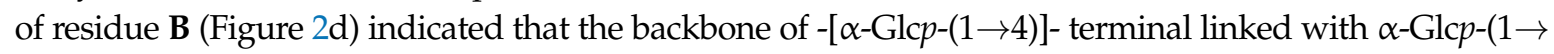
residues. The linkage between Residues $\mathbf{B}$ and $\mathbf{C}$ was supported by the HMBC correlation of $\mathrm{H}-1$ of Residue C with C-4 of Residue B (Figure 2d). Similarly, the cross-peak of H-1 (A) to C-3 (C) at $\delta 5.43 / 77.9$, indicated that Residue A was substituted at the $\mathrm{O}-3$ position of Residue $\mathbf{C}$ by side chains.

Table 2. ${ }^{1} \mathrm{H}$ NMR and ${ }^{13} \mathrm{C}$ NMR chemical shifts $(\delta)$ of the OP- 1 from the oyster recorded in $\mathrm{D}_{2} \mathrm{O}$ at $27{ }^{\circ} \mathrm{C}$.

\begin{tabular}{|c|c|c|c|c|c|c|c|}
\hline \multirow{2}{*}{ Residues } & \multicolumn{7}{|c|}{ Chemical Shifts ${ }^{1} \mathrm{H} /{ }^{13} \mathrm{C}$ (ppm) } \\
\hline & 1 & 2 & 3 & 4 & 5 & 6(a) & 6(b) \\
\hline \multirow{2}{*}{ A $\alpha$-Glcp- $(1 \rightarrow$} & 5.43 & 3.74 & 3.74 & 3.79 & 3.74 & 3.94 & \multirow[b]{2}{*}{3.86} \\
\hline & 100.4 & 71.7 & 73.5 & 73.2 & 72.4 & 61 & \\
\hline \multirow{2}{*}{ B $\alpha-(1 \rightarrow 4)-$ Glc $p$} & 5.43 & 3.64 & 3.7 & 3.69 & 3.91 & 3.94 & \multirow{2}{*}{3.86} \\
\hline & 100.4 & 71.9 & 73.6 & $\underline{78}$ & 71.8 & 61 & \\
\hline \multirow{2}{*}{$\mathrm{C} \alpha-(1 \rightarrow 3,4)-\mathrm{Glc} p$} & 5.43 & 3.68 & 4.03 & 3.73 & 3.71 & 3.94 & \multirow{2}{*}{3.86} \\
\hline & 100.4 & 72.3 & 73.8 & 77.9 & 72.1 & 61 & \\
\hline
\end{tabular}

Underlined bold numbers represent glycosylation sites. 
(a)

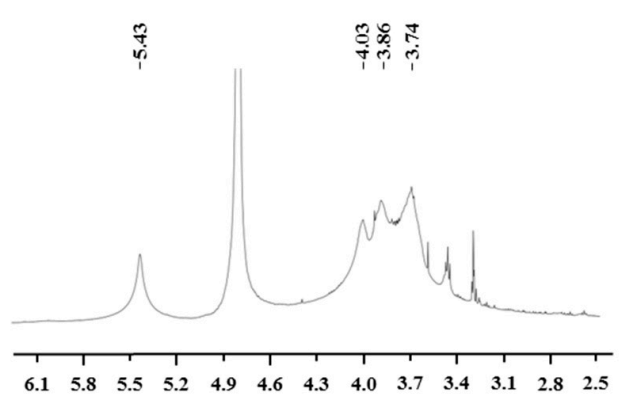

ppm (c)

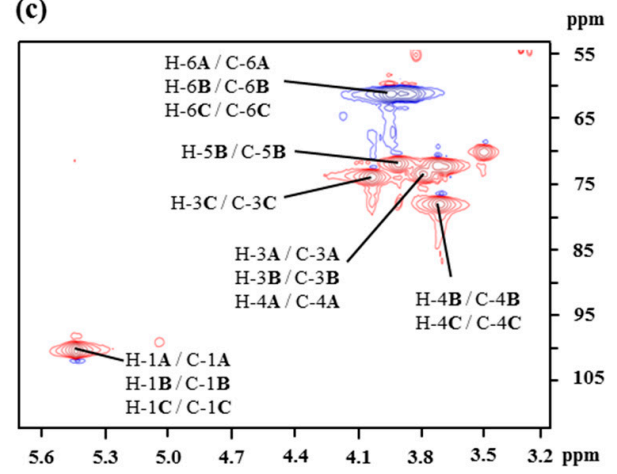

(b)

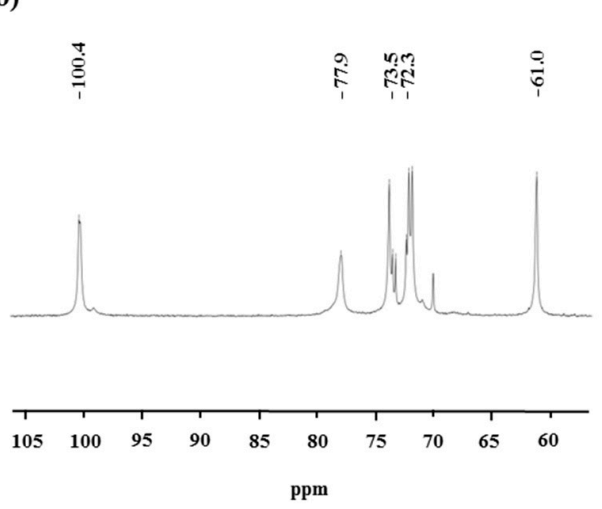

(d)

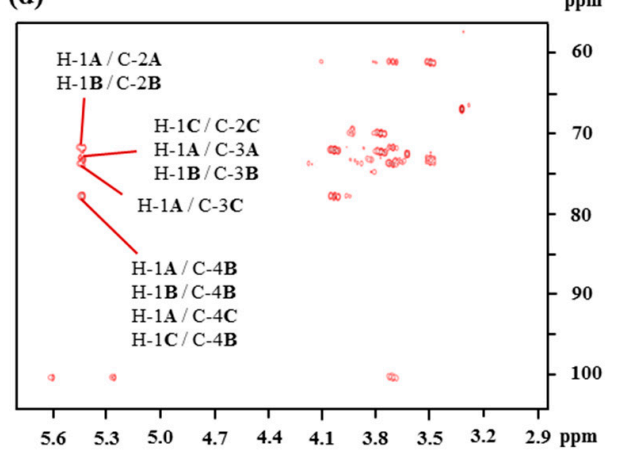

(e)

A

$$
\alpha-\mathrm{D}-\mathrm{Glc} p
$$

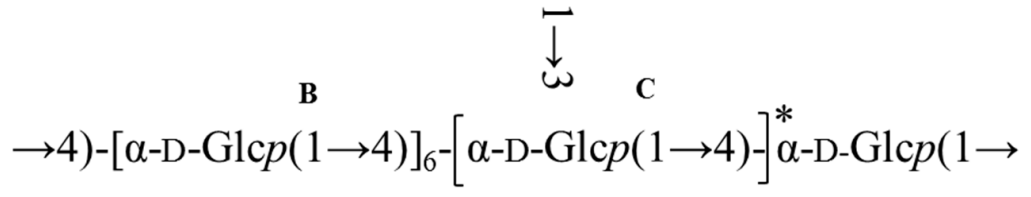

Figure 2. ${ }^{1} \mathrm{H}$ NMR (a), ${ }^{13} \mathrm{C}$ NMR (b), HSQC (c), and HMBC (d) spectra of the OP-1 from oysters recorded in $\mathrm{D}_{2} \mathrm{O}$ at $27^{\circ} \mathrm{C}$. (e) The predicted structure of OP-1 isolated from the oyster.

The NMR technique is a powerful tool for structural elucidation. However, it is limited and difficult to obtain the complete structure of polysaccharides by the interpretation of NMR spectra, for the NMR resonances of polysaccharides always overlap. Therefore, the proposed structure of OP-1 is mainly based on the data obtained from methylation and then further confirmed by NMR data. After comprehensive composition analysis, methylation analysis, and NMR experiments, it can be concluded that the repeating unit of OP-1 has a backbone of $(1 \rightarrow 4)$ - $\alpha$-D-glucosyl residues, and has $\alpha$-D-glucosyl residues on the terminal of the side chains at the $O-3$ position. The predicted structure of $\mathrm{OP}-1$ is presented in Figure 2e.

More recently, the $\alpha$-glucan from aquatic species showed interesting pharmacological activities has been attracting the attention of scientists seeking to explore new potent biological activities [27]. A water-soluble glucan isolated from Cyclina sinensis showed significant scavenging activities on superoxide radicals and an inhibitory effect in vitro on human gastric cancer cells [28]. A water-soluble $\alpha$-glucan was isolated from foot muscle of Bellamya purificata by Zhang et al. [29], and significant 
anti-inflammatory activity was found. This glucan has a backbone of $\alpha-(1 \rightarrow 4)$-D-glucopyranosyl and branches at O-6 of $\alpha-(1 \rightarrow 6)$-D-glucopyranosyl residues [29]. Altogether, these data point to the idea that the $\alpha$-glucan from mollusks contributes to the diversion of the immune host response.

\subsection{Cell Proliferation and IL-2 Production}

As the first step toward understanding the anti-tumor activity of OP-1, the effects of OP-1 on lymphocyte proliferation were investigated. As shown in Figure 3a, OP-1 was found to cause a dose-dependent increase at concentrations from 10 to $250 \mu \mathrm{g} / \mathrm{mL}$ in spleen lymphocyte cell proliferation. Cell proliferation was increased $64.44 \%$ when OP-1 at the concentration of $10 \mu \mathrm{g} / \mathrm{mL}$, and ConA at the concentration of $5 \mu \mathrm{g} / \mathrm{mL}$. The immune system plays a significant role in anti-tumor activity. Numerous reports have suggested that anti-tumor activity of the polysaccharides is mediated through a thymus-dependent immune mechanism [30]. Lymphocyte proliferation of splenocytes is a direct indicator of cellular immunity.

(a)

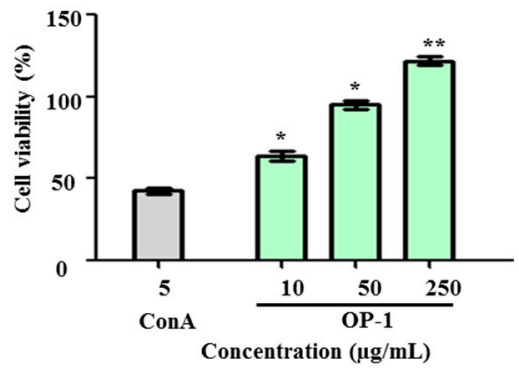

(d)

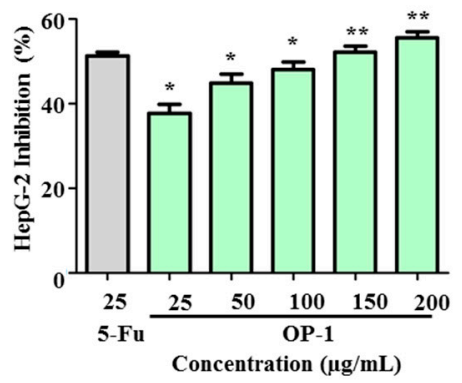

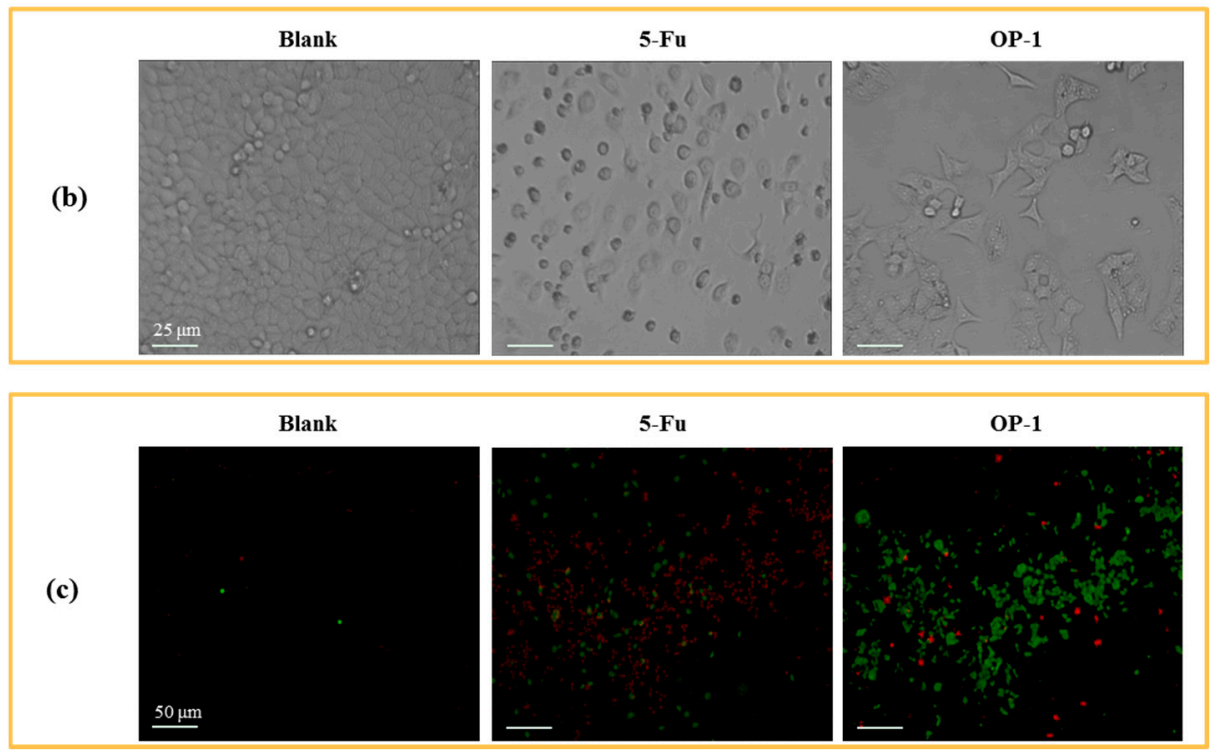

Figure 3. (a) Effects of OP-1 on the viability of spleen lymphocyte. (b) Morphology of HepG2 cells under inverted microscope. (c) Effects of OP-1 on phagocytosis of HepG2 cells in vivo. Fluorescence microscopic image of HepG2 cells were incubated with FITC-labeled annexin V and PI. (d) Inhibitory effect of OP-1 on HepG2 cells. ${ }^{*} p<0.05 ;{ }^{* *} p<0.01$ vs. control.

The activated immune cells also secrete some cytokines, such as IL-1, IL-2, IL-6, TNF- $\alpha$, and IFN- $\gamma$. The effects of OP-1 treatment on the secretion of IL-2 are listed in Table 3. The results showed that OP-1 could increase lymphocyte secretion of IL-2. A similar result was observed in a study by Cheng et al. [5], in which it was demonstrated that lymphocytes exposed to oyster polysaccharides significantly increased the production of IL-4 and IFN- $\gamma$. Thus, OP-1 may have an indirect role in 
anti-tumor activity through cell proliferation promotion and the release of the lymphocyte-produced effector molecule, IL-2.

Table 3. Effect of oyster polysaccharides (OP-1) on IL-2 secretion via lymphocyte.

\begin{tabular}{ccc}
\hline Sample & IL-2 $\mathbf{( p g / m L )}$ & SI (\%) \\
\hline Blank & $167.09 \pm 3.92$ & - \\
Con A & $239.46 \pm 3.28$ & $43.31 \pm 2.73$ \\
OP-1 & $439.80 \pm 2.72{ }^{* *}$ & $149.87 \pm 0.18^{* *}$ \\
\hline \multicolumn{3}{c}{ Mean \pm SD; $n=3 .{ }^{* *} p<0.01$ vs. control. }
\end{tabular}

\subsection{Cytotoxic Activity on HepG2 and Madin-Daby Canine Kidney (MDCK) Cell}

After $24 \mathrm{~h}$ treatment with OP-1, human liver cancer HepG2 cells were examined by an inverted microscope. In Figure 3b, the number of cells in the OP-1 group obviously decreased when compared with the blank group (Figure 3b). OP-1 was shown to be dose-dependent on the inhibition of HepG2 cell proliferation (Table 4). At concentrations of $100 \mu \mathrm{g} / \mathrm{mL}$ and $200 \mu \mathrm{g} / \mathrm{mL}$, the inhibitory ratios were $47.23 \%$ and $52.94 \%$, respectively. In contrast to 5 -fluorouracil (5-Fu), OP-1 had less anti-tumor activity on HepG2 cells (50.72\% and 39.70\%, respectively) when the same dose of OP-1 ( $25 \mu \mathrm{g} / \mathrm{mL})$ was used.

Table 4. Cytotoxicity of OP-1 at different concentrations against human liver cancer HepG2 cells and Madin-Daby canine kidney MDCK cells in vitro.

\begin{tabular}{|c|c|c|c|c|}
\hline \multirow{2}{*}{$\begin{array}{c}\text { Concentration } \\
\mu \mathrm{g} / \mathrm{mL}\end{array}$} & \multicolumn{2}{|c|}{ HepG2 Cells } & \multicolumn{2}{|c|}{ MDCK Cells } \\
\hline & $5-\mathrm{Fu}$ & OP-1 & $5-\mathrm{Fu}$ & OP-1 \\
\hline 25 & $50.72 \pm 0.71$ & $39.70 \pm 3.18$ & $42.65 \pm 1.31$ & $-6.05 \pm 0.96$ \\
\hline 50 & & $46.20 \pm 2.61$ & & $-4.50 \pm 1.13$ \\
\hline 100 & & $47.23 \pm 2.03$ & & $-9.78 \pm 4.00$ \\
\hline 150 & & $52.24 \pm 1.16$ & & $-14.01 \pm 0.30 *$ \\
\hline 200 & & $55.82 \pm 2.03$ & & $-15.48 \pm 6.65^{* *}$ \\
\hline
\end{tabular}

Mean $\pm \mathrm{SD} ; n=3 .{ }^{*} p<0.05 ;{ }^{* *} p<0.01$ vs. control.

The anti-tumor activity was further confirmed by a HepG2 phagocytic assay. Fluorescein isothiocyanate-conjugated (FITC)-labeled annexin V and propidium iodide (PI) uptake in HepG2 cells were compared between the positive control and the blank groups. HepG2 cells displayed phosphatidylserine on their outer cell membranes and were readily stained with annexin $\mathrm{V}$ in the early stages of apotosis. At later stages of apoptosis, PI moved across the cell membrane and bound to cellular DNA. Apoptotic cells could then be detected after they were double-stained with annexin $\mathrm{V}$ and PI. The results showed that OP-1 $(15 \mu \mathrm{g} / \mathrm{mL})$ could obviously enhance phagocytic activities, which displayed a higher FITC-fluorescence intensity when compared with the untreated control groups (Figure 3c,d).

Cytotoxicity assays for anti-tumor agents are important chemotherapeutic parameters. Therefore, cytotoxic effects were also determined in Madin-Daby canine kidney MDCK cells. OP-1 at doses of 25-250 $\mu \mathrm{g} / \mathrm{mL}$ did not show cytotoxicity, while 5-Fu had a cytotoxic effect on MDCK cells (Table 4). The results suggest that OP-1 had no toxic effects at any of the tested concentrations.

Taking into account the increasing incidence of cancer in various organs, effective agents or compounds are urgently needed to control this problem. Most of the polysaccharides are considered to have a wide variety of biological activities. A brief review of recent advances in applications of polysaccharides derived from marine origin for pharmacological activities has been reported [31]. Over the last few decades, the functional food and pharmaceutical industries have shown a strong interest in polysaccharides derived from marine sources in general. The main reason for this increased interest is that polysaccharides are non-toxic, natural, less expensive, and abundantly available in nature. Therefore, oyster polysaccharides hold great promise as a potential source of new therapeutic agents. 
Based on the above results describing its biological activities, OP-1 had significant anti-tumor activities against liver cancer and HepG2 cells and had no direct toxicity to the normal cells.

\section{Materials and Methods}

\subsection{Materials}

Acetic anhydride was purchased from Sigma-Aldrich (St. Louis, MO, USA). Dimethyl sulfoxide (DMSO; 99.9\%) was purchased from Alfa Aesar (Ward Hill, MA, USA). Methyl iodide was purchased from VWR International (Lutterworth, UK). Other reagents were analytical grade.

\subsection{Extraction of Polysaccharides from Oyster}

Oyster meat was stripped from the shells, and then homogenized in a blender. The homogeneous mixture was extracted with water at $90{ }^{\circ} \mathrm{C}$ for $3 \mathrm{~h}$. After cooling to room temperature, the extract was centrifuged at $4000 \times g$ for $15 \mathrm{~min}$ and the supernatant was collected. Total sugar content was determined by the phenol-sulfuric acid assay with glucose as the standard [32]. The protein concentration of each sample was determined by a BCA protein assay kit (Thermo Fisher Scientific Inc., Rockford, IL, USA).

\subsection{Preparation of Aqueous Two-Phase Systems}

Aqueous PEG/salt systems were prepared by weighing the appropriated amounts of PEG stock solution, ammonium sulfate stock solution, oyster extract, and water, to a final weight of $8 \mathrm{~g}$, in order to achieve the desired composition. Ethanol/salt systems were prepared by weighing the appropriated amounts of ethanol, ammonium sulfate stock solution, oyster extract, and water to a final weight of $8 \mathrm{~g}$. The two phases were mingled thoroughly and stood for $10 \mathrm{~min}$, and the two phases were then completely separated. The partitioning experiments were carried out at room temperature.

The TLL was determined by the square root of the sum of the squares of the difference between the top and bottom phases. The volume ratio was obtained dividing the volume of top phase by the volume of the bottom phase. The extraction efficiency $(E, \%)$ was the concentration of the polysaccharides or proteins partitioned in the bottom phase to the amount of the sample added. The extraction efficiency was calculated with the following equation:

$$
E(\%)=\frac{C_{t} \times V_{t}}{m_{0}} \times 100 \%
$$

where $C_{t}$ is the concentration of the upper phase, $V_{t}$ is the volume of the upper phase, and $m_{o}$ is the amount of the sample added.

\subsection{Chemical Characterization}

\subsubsection{Monosaccharide Composition Analysis}

Polysaccharides (5 mg) were treated with $1 \mathrm{~mol} / \mathrm{L} \mathrm{H}_{2} \mathrm{SO}_{4}(2 \mathrm{~mL})$ at $100{ }^{\circ} \mathrm{C}$ for $4 \mathrm{~h}$. After hydrolysis, the mixture was neutralized with $\mathrm{Ba}(\mathrm{OH})_{2}$. The hydrolysate was detected by Agilent 1200 HPLC system (Agilent, Santa Clara, CA, USA) equipped with an ESLD (Alltech, Deerfield, IL, USA). Chromatographic separation was performed at $25^{\circ} \mathrm{C}$ using a column of Prevail Carbohydrate ES column $(250 \mathrm{~mm} \times 4.6 \mathrm{~mm}, 5 \mu \mathrm{m}$, Alltech). The mobile phase consisted of acetonitrile and water $(v / v$, $75: 25)$ at a flow rate of $1.0 \mathrm{~mL} / \mathrm{min}$. The drift tube temperature for ELSD was set at $83^{\circ} \mathrm{C}$, and the nitrogen flow rate was $2.1 \mathrm{~L} / \mathrm{min}$. The injection volume was $5 \mu \mathrm{L}$.

\subsubsection{Methylation Analysis}

Purified polysaccharides were methylated according to a previous report [33]. The polysaccharides $(5 \mathrm{mg}$ ) were dissolved in DMSO $(5 \mathrm{~mL})$; subsequently, $20 \mathrm{mg}$ of $\mathrm{NaOH}$ 
and $150 \mu \mathrm{L}$ of $\mathrm{CH}_{3} \mathrm{I}$ were added. After reaction for $4 \mathrm{~h}$ in the dark, water and dichloromethane were then added. The dichloromethane layer was dried under vacuum at $50{ }^{\circ} \mathrm{C}$. Subsequently, the residue was hydrolyzed with TFA for $6 \mathrm{~h}$ at $105^{\circ} \mathrm{C}$. The hydrolyzed product was also dried under vacuum at $50{ }^{\circ} \mathrm{C}$, and the residue was subsequently reduced with $\mathrm{NaBH}_{4}$, neutralized with acetic acid, and acetylated with acetic anhydride to obtain a mixture of partially $O$-methylated alditol acetates. Qualitative and quantitative analyses were conducted using GC-MS.

\subsection{3. ${ }^{1} \mathrm{H}$ and ${ }^{13} \mathrm{C}$ NMR Test}

Purified polysaccharides $\left(25 \mathrm{mg}\right.$ ) were dissolved in $1 \mathrm{~mL}$ of $\mathrm{D}_{2} \mathrm{O}$ at room temperature. NMR spectra were recorded on a Bruker Avance 400 spectrometer (Bruker BioSpin, Billerica, MA, USA) at $400 \mathrm{MHz}$ for ${ }^{1} \mathrm{H}$ and $100 \mathrm{MHz}$ for ${ }^{13} \mathrm{C}$.

\subsection{Anti-Tumor Activities of Oyster Polysaccharide}

\subsubsection{Preparation of Spleen Lymphocytes}

The extirpated spleens were minced into small pieces with knife and suspended in an RPMI 1640 medium. Single-cell suspension was filtered by a sterile sieve mesh. The cells were supplemented with $6 \mathrm{~mL}$ of lysis buffer to remove the red blood cells, and then washed 3 times with cold phosphate-buffered saline. Subsequently, the cells were adjusted to a concentration of $1 \times 10^{6} \mathrm{cells} / \mathrm{mL}$ in RPMI-1640 medium. The suspended cells were then collected.

\subsubsection{Cell Proliferation Assay}

Cells $\left(1 \times 10^{4}\right.$ cells /well) were treated with serial concentrations $(10,50$, and $250 \mu \mathrm{g} / \mathrm{mL})$ of OP-1 and $5.0 \mu \mathrm{g} / \mathrm{mL}$ ConA for $24 \mathrm{~h}$, respectively. Cell culture RPMI- 1640 medium was used as a blank group. Following incubation at $37^{\circ} \mathrm{C}$ and $5 \% \mathrm{CO}_{2}$, MTT $(0.5 \mathrm{mg} / \mathrm{mL})$ was added and co-incubated for an additional $4 \mathrm{~h}$ in the dark. After cultivation, the supernatants were removed, and the insoluble purple-colored formazan MTT was dissolved in sodium dodecyl sulfate lysis buffer (sodium dodecyl sulfate, isopropanol, and $\mathrm{HCl}$ ). The absorbance values were recorded at $570 \mathrm{~nm}$, and the cell viability was calculated as the percentage of the ratios of absorbance between the treated and blank groups.

\subsubsection{Measurement of IL-2}

Cells $\left(1 \times 10^{6}\right.$ cells $\left./ \mathrm{mL}\right)$ were exposed to $250 \mu \mathrm{g} / \mathrm{mL}$ of OP- 1 and $5.0 \mu \mathrm{g} / \mathrm{mL}$ ConA for $24 \mathrm{~h}$ at $37^{\circ} \mathrm{C}$ and $5 \% \mathrm{CO}_{2}$. After incubation, the cell supernatants were then collected via centrifugation at $1200 \times g$ for $5 \mathrm{~min}$. The concentrations of IL-2 were assayed via an ELISA kit.

\subsubsection{HepG2 and MDCK Cells Proliferation Assay}

HepG2 cells $\left(4 \times 10^{4}\right.$ cells $\left./ \mathrm{mL}\right)$ and MDCK cells $\left(4 \times 10^{4}\right.$ cells $\left./ \mathrm{mL}\right)$ were plated on 96-well plates, separately. After the cells were incubated for $24 \mathrm{~h}$, the cells were supplemented with serial concentrations of OP-1 and 5-Fu, respectively. Cell culture DMEM medium was used as the control group. Following incubation at $37^{\circ} \mathrm{C}$ and $5 \% \mathrm{CO}_{2}$, MTT $(0.5 \mathrm{mg} / \mathrm{mL})$ was added and co-incubated for an additional $4 \mathrm{~h}$ in the dark. After cultivation, the supernatants were removed, and the residues were dissolved with DMSO. The absorbance values were recorded at $570 \mathrm{~nm}$, and the percentage of cell inhibition (\%) was calculated from the decrease in absorbance of treated samples as compared with the control cells, which is calculated using the following formula:

$$
\text { Cell inhibition }(\%)=\left(A_{c}-A_{s}\right) / A_{\mathcal{c}} \times 100 \%
$$

where $A_{c}$ is the absorbance value of the control, and $A_{s}$ is the absorbance value of the test compound. 


\subsubsection{Phagocytic Assay}

FITC-labeled annexin V was used for the phagocytic assay of HepG2. Cells $\left(4 \times 10^{4}\right)$ were cultured in a 96-well plate with additional OP-1 and 5-Fu for $24 \mathrm{~h}$, respectively. The cell culture medium was used as a blank group. Then, the cells were washed with PBS and then stained with $200 \mu \mathrm{L}$ of labeling solution containing FITC-labeled annexin V and PI for $10 \mathrm{~min}$ at room temperature. An observation was made at a final magnification of $400 \times$ using a fluorescence microscope. The phagocytic ability expressed as a mean fluorescence intensity (MFI)-FITC between the cells in treatments group and those of the blank group.

\subsection{Statistical Analysis}

Data were expressed as mean \pm standard errors based on at least three independent experiments for each sample. Statistical significance was calculated via one-way analysis of variance test followed by a least significant difference test. Values of $p<0.05$ were considered to be statistical significant.

\section{Conclusions}

A simple and efficient ATPS has been successfully applied to separate oyster polysaccharides and proteins. Under optimum ATPS conditions, polysaccharides were separated in the bottom phase, and the extraction efficiency was $67.02 \%$. This ATPS is a simple, fast, and green separation system that can be used to isolate and purify oyster polysaccharides on a large scale. These polysaccharides (OP-1)

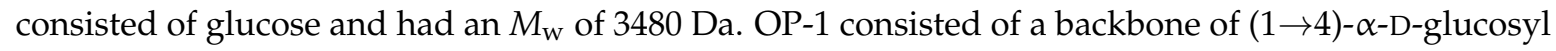
with $\alpha$-D-glucosyl residues on the terminal of the side chains at the O-3 position. Moreover, OP- 1 can stimulate the phagocytic activity and IL-2 production. OP-1 showed significant anti-tumor activity against HepG2 cells in vitro and had no direct toxicity to normal cells. These results can guide the direction of future research toward novel functional food or therapeutic agents.

Acknowledgments: This research was financially supported by grants from the National Natural Science Foundation of China (21476135), the Educational Commission of Guangdong Province, China (2016KZDXM014), the Ocean and Fisheries Administration Project of Guangdong Province, China (2017), and the Research and Development Start-Up Foundation of Shantou University (NTF16014).

Author Contributions: Kit-Leong Cheong and Li-Xuan Xia performed the experiments and data analysis, and wrote the paper; Yang Liu contributed to the conception and design of the experiments. All authors reviewed the manuscript and approved the final version.

Conflicts of Interest: The authors declare no conflict of interest.

\section{References}

1. Watanabe, M.; Fuda, H.; Okabe, H.; Joko, S.; Miura, Y.; Hui, S.-P.; Yimin; Hamaoka, N.; Miki, E.; Chiba, H. Oyster extracts attenuate pathological changes in non-alcoholic steatohepatitis (NASH) mouse model. J. Funct. Foods 2016, 20, 516-531. [CrossRef]

2. Wang, Q.; Li, W.; He, Y.; Ren, D.; Kow, F.; Song, L.; Yu, X. Novel antioxidative peptides from the protein hydrolysate of oysters (Crassostrea talienwhanensis). Food Chem. 2014, 145, 991-996. [CrossRef] [PubMed]

3. Watanabe, M.; Fuda, H.; Jin, S.; Sakurai, T.; Ohkawa, F.; Hui, S.-P.; Takeda, S.; Watanabe, T.; Koike, T.; Chiba, H. Isolation and characterization of a phenolic antioxidant from the pacific oyster (Crassostrea gigas). J. Agric. Food Chem. 2012, 60, 830-835. [CrossRef] [PubMed]

4. Achour, A.; Lachgar, A.; Astgen, A.; Chams, V.; Bizzini, B.; Tapiero, H.; Zagury, D. Potentialization of IL-2 effects on immune cells by oyster extract (JCOE) in normal and HIV-infected individuals. Biomed. Pharmacother. 1997, 51, 427-429. [CrossRef]

5. Cheng, J.Y.; Ng, L.T.; Lin, C.L.; Jan, T.R. Pacific oyster-derived polysaccharides enhance antigen-specific T helper (Th)1 immunity in vitro and in vivo. Immunopharmacol. Immunotoxicol. 2013, 35, 235-240. [CrossRef] [PubMed] 
6. Itoh, N.; Kamitaka, R.; Takahashi, K.G.; Osada, M. Identification and characterization of multiple $\beta$-glucan binding proteins in the Pacific oyster, Crassostrea gigas. Dev. Comp. Immunol. 2010, 34, 445-454. [CrossRef] [PubMed]

7. Shi, X.; Ma, H.; Tong, C.; Qu, M.; Jin, Q.; Li, W. Hepatoprotective effect of a polysaccharide from Crassostrea gigas on acute and chronic models of liver injury. Int. J. Biol. Macromol. 2015, 78, 142-148. [CrossRef] [PubMed]

8. Wang, T.; Ding, J.; Li, H.; Xiang, J.; Wen, P.; Zhang, Q.; Yin, L.; Jiang, W.; Shen, C. Antihypertensive activity of polysaccharide from Crassostrea gigas. Int. J. Biol. Macromol. 2016, 83, 195-197. [CrossRef] [PubMed]

9. Wu, S.; Huang, X. Preparation and antioxidant activities of oligosaccharides from Crassostrea gigas. Food Chem. 2017, 216, 243-246. [CrossRef] [PubMed]

10. Hu, X.; Tao, N.; Wang, X.; Xiao, J.; Wang, M. Marine-derived bioactive compounds with anti-obesity effect: A review. J. Funct. Foods 2016, 21, 372-387. [CrossRef]

11. Ferreira, S.S.; Passos, C.P.; Madureira, P.; Vilanova, M.; Coimbra, M.A. Structure-function relationships of immunostimulatory polysaccharides: A review. Carbohydr. Polym. 2015, 132, 378-396. [CrossRef] [PubMed]

12. Cheong, K.-L.; Meng, L.-Z.; Chen, X.-Q.; Wang, L.-Y.; Wu, D.-T.; Zhao, J.; Li, S.-P. Structural elucidation, chain conformation and immuno-modulatory activity of glucogalactomannan from cultured Cordyceps sinensis fungus UM01. J. Funct. Foods 2016, 25, 174-185. [CrossRef]

13. Shin, M.-S.; Lee, H.; Hong, H.-D.; Shin, K.-S. Characterization of immunostimulatory pectic polysaccharide isolated from leaves of Diospyros kaki Thumb. (Persimmon). J. Funct. Foods 2016, 26, 319-329. [CrossRef]

14. Liu, Y.; Feng, Y.; Lun, J. Aqueous two-phase countercurrent distribution for the separation of c-phycocyanin and allophycocyanin from Spirulina platensis. Food Bioprod. Process. 2012, 90, 111-117. [CrossRef]

15. Liu, X.; Mu, T.; Sun, H.; Zhang, M.; Chen, J. Optimisation of aqueous two-phase extraction of anthocyanins from purple sweet potatoes by response surface methodology. Food Chem. 2013, 141, 3034-3041. [CrossRef] [PubMed]

16. Li, Z.; Pei, Y.; Wang, H.; Fan, J.; Wang, J. Ionic liquid-based aqueous two-phase systems and their applications in green separation processes. TrAC Trends Anal. Chem. 2010, 29, 1336-1346. [CrossRef]

17. Ao, G.; Khripin, C.Y.; Zheng, M. DNA-controlled partition of carbon nanotubes in polymer aqueous two-phase systems. J. Am. Chem. Soc. 2014, 136, 10383-10392. [CrossRef] [PubMed]

18. Desai, R.K.; Streefland, M.; Wijffels, R.H.; Eppink, M.H.M. Extraction and stability of selected proteins in ionic liquid based aqueous two phase systems. Green Chem. 2014, 16, 2670-2679. [CrossRef]

19. Liu, Y.; Zhang, Y.; Wu, X.; Yan, X. Effect of excluded-volume and hydrophobic interactions on the partition of proteins in aqueous micellar two-phase systems composed of polymer and nonionic surfactant. Fluid Phase Equilib. 2016, 429, 1-8. [CrossRef]

20. Spyropoulos, F.; Portsch, A.; Norton, I.T. Effect of sucrose on the phase and flow behaviour of polysaccharide/protein aqueous two-phase systems. Food Hydrocoll. 2010, 24, 217-226. [CrossRef]

21. Rajendran, V.; Puvendran, K.; Guru, B.R.; Jayaraman, G. Design of aqueous two-phase systems for purification of hyaluronic acid produced by metabolically engineered Lactococcus lactis. J. Sep. Sci. 2016, 39, 655-662. [CrossRef] [PubMed]

22. Xing, J.-M.; Li, F.-F. Purification of aloe polysaccharides by using aqueous two-phase extraction with desalination. Nat. Prod. Res. 2009, 23, 1424-1430. [CrossRef] [PubMed]

23. Wang, Y.; Hu, X.; Han, J.; Ni, L.; Tang, X.; Hu, Y.; Chen, T. Integrated method of thermosensitive triblock copolymer-salt aqueous two phase extraction and dialysis membrane separation for purification of lycium barbarum polysaccharide. Food Chem. 2016, 194, 257-264. [CrossRef] [PubMed]

24. Tao, Y.; Zhang, L.; Yan, F.; Wu, X. Chain conformation of water-insoluble hyperbranched polysaccharide from fungus. Biomacromolecules 2007, 8, 2321-2328. [CrossRef] [PubMed]

25. Zhang, W.; Li, P.; Song, D.; Niu, H.; Shi, S.; Wang, S.; Duan, J. Structural characterization and biological activities of two $\alpha$-glucans from Radix Paeoniae Alba. Glycoconj. J. 2016, 33, 147-157. [CrossRef] [PubMed]

26. Bittencourt, V.C.B.; Figueiredo, R.T.; Silva, R.B.D.; Mourãosá, D.S.; Fernandez, P.L.; Sassaki, G.L.; Mulloy, B.; Bozza, M.T.; Barretobergter, E. An $\alpha$-glucan of Pseudallescheria boydii is involved in fungal phagocytosis and toll-like receptor activation. J. Biol. Chem. 2006, 281, 22614-22623. [CrossRef] [PubMed]

27. Liu, D.; Liao, N.; Ye, X.; Hu, Y.; Wu, D.; Guo, X.; Zhong, J.; Wu, J.; Chen, S. Isolation and structural characterization of a novel antioxidant mannoglucan from a marine bubble snail, Bullacta exarata (Philippi). Mar. Drugs 2013, 11, 4464-4477. [CrossRef] [PubMed] 
28. Jiang, C.; Wang, M.; Liu, J.; Gan, D.; Zeng, X. Extraction, preliminary characterization, antioxidant and anticancer activities in vitro of polysaccharides from Cyclina sinensis. Carbohydr. Polym. 2011, 84, 851-857. [CrossRef]

29. Zhang, H.; Ye, L.; Wang, K. Structural characterization and anti-inflammatory activity of two water-soluble polysaccharides from Bellamya purificata. Carbohydr. Polym. 2010, 81, 953-960. [CrossRef]

30. Zhang, M.; Cui, S.W.; Cheung, P.C.K.; Wang, Q. Antitumor polysaccharides from mushrooms: A review on their isolation process, structural characteristics and antitumor activity. Trends Food Sci. Technol. 2007, 18, 4-19. [CrossRef]

31. Mayakrishnan, V.; Kannappan, P.; Abdullah, N.; Ahmed, A.B.A. Cardioprotective activity of polysaccharides derived from marine algae: An overview. Trends Food Sci. Technol. 2013, 30, 98-104. [CrossRef]

32. DuBois, M.; Gilles, K.A.; Hamilton, J.K.; Rebers, P.T.; Smith, F. Colorimetric method for determination of sugars and related substances. Anal. Chem. 1956, 28, 350-356. [CrossRef]

33. Ciucanu, I.; Kerek, F. A simple and rapid method for the permethylation of carbohydrates. Carbohydr. Res. 1984, 131, 209-217. [CrossRef]

(C) 2017 by the authors. Licensee MDPI, Basel, Switzerland. This article is an open access article distributed under the terms and conditions of the Creative Commons Attribution (CC BY) license (http:/ / creativecommons.org/licenses/by/4.0/). 